\title{
Marcin Telicki \\ Świadectwo obrazu. Związki ekfrazy i pamięci w Zobaczonym Julii Hartwig
}

ABSTRACT. Telicki Marcin, Świadectwo obrazu. Związki ekfrazy i pamięci w "Zobaczonym" Julii Hartwig [The evidence of the image. The relationships of ekphrasis to memory in Julia Hartwig's Zobaczone (What's been seen)]. "Przestrzenie Teorii” 11. Poznań 2009, Adam Mickiewicz University Press, pp. 63-82. ISBN 978-83-232-1986-6. ISSN 1644-6763.

In the article The evidence of the image..., the author reflects on two important problems in modern culture: considers the role of ekphrasis - the introduction of which connotes the concepts of iconicity, vividness and representation; and memory processes derived from descriptions of pieces of painting (but also views of nature). It appears that the change in time, that introduces changes to the perception, is shared by the two phenomena. Theoretical considerations are developed and legitimised by interpretations of poems from the volume Zobaczone. In her poetry, Julia Hartwig, sometimes considered as one of the Old Masters of poetry, very consistently combines interest in the visuality of the world and problems of recording continuity. Hence, it is advisable to analyse her poems as a play between the elusive image and its material evidence.

Michel Foucault w eseju Panny dworskie (Las Meninas) rozważa za punkt wyjścia obierając słynny obraz Velázqueza - wiele problemów związanych $\mathrm{z}$ odbiorem dzieła wizualnego. Istotna konkluzja, która wyłania się $\mathrm{z}$ tych refleksji, stanowi dogodne wprowadzenie do tematu ekfrastyczności tomu Zobaczone:

Słowo i to, co dostępne oku - są nawzajem do siebie niesprowadzalne: na próżno opowiadamy, co widzimy; to, co widzimy, nie mieści się nigdy w tym, co mówimy, i nadaremno ukazujemy przez obrazy, metafory, porównania - to, co mówimy; miejsce, w jakim one rozbłyskują, nie jest miejscem rozpościeranym przez oczy, lecz miejscem określanym przez następstwo syntaktyczne. Otóż imię własne w tej grze jest tylko sztuczką: pozwala pokazać palcem, to znaczy złożyć je dogodnie jedną ku drugiej, jakby były współmierne ${ }^{1}$.

Nazwa i rzecz, wywodzi dalej Foucault, nigdy jednak nie są współmierne i jedyne co możemy zrobić, wiedząc o tym, to podjąć nieskończony opis, który choć w małym stopniu przybliży nas do istoty obrazu (i dalej: do istoty rzeczy). Poruszany przez filozofa problem jest złożony, na potrzeby mojej analizy wybieram z niego to, co łączy się z ekfrazą i hypoty-

1 M. Foucault, Stowa i rzeczy. Archeologia nauk humanistycznych, przel. T. Komendant, Gdańsk 2000, s. 30. 
pozą. Ekfraza doczekała się od lat 90 . obszernej bibliografii ${ }^{2}$ i stała się jednym $\mathrm{z}$ ulubionych środków opisywanych przez teoretyków literatury. Hypotypoza ma zbliżony zakres znaczeniowy, ale - jak zauważa Adam Dziadek - nie jest z ekfrazą tożsama. Dlatego warto na początku ustalić definicje i wprowadzić rozróżnienia.

Ekfraza, w podstawowym sensie, jest poetyckim ${ }^{3}$ opisem konkretnego dzieła sztuki - na tyle konkretnego, by czytelnik mógł je rozpoznać, idąc za pozostawionymi w tekście wskazówkami ${ }^{4}$. Mogą nimi być: tytuł lub podtytuł tekstu taki sam jak dzieła sztuki, nazwisko autora dzieła, charakterystyczne elementy opisu lub odwołanie do stylu, konwencji czy techniki dzieła ${ }^{5}$. Hypotypoza, która będzie zajmować mnie w mniejszym stopniu, tym różni się od ekfrazy, że daje opis bardziej schematyczny i nie pozwala rozpoznać określonego obrazu 6 .

Dziadek powtarza za J.-L. Nancy, że

żaden tekst nie ma jedynego właściwego sobie obrazu ani żaden obraz nie ma właściwego sobie tekstu. Ten „nierozstrzygalnik”, czy raczej podwójne związanie, stawiam w centrum problematyki relacji pomiędzy obrazami i tekstami. [...] Metaforycznie (i zarazem "obrazowo") można by tę relację opisać za pomocą chiazmu. Graficzny obraz tej figury opiera się na greckiej literze X, w której dwie proste jednocześnie przecinają się i rozchodzą $w$ dwu różnych kierunkach. Jest to figura podwójnego gestu, podwójnej przynależności, w której splata się słowo i obraz. To również figura doskonale ilustrująca wzajemne przenikanie się ukrytych w obrazach sensów ${ }^{7}$.

${ }^{2}$ M.P. Markowski, Ekphrasis. Uwagi bibliograficzne z dolqczeniem krótkiego komentarza, „Pamiętnik Literacki” 1999, z. 2, s. 229-236.

3 Stownik terminów literackich zawęża stosowanie ekfrazy do poezji, nowsze ujęcia proponują jednak rozpatrywać ten specyficzny opis w oderwaniu od konkretnego gatunku czy rodzaju literackiego. Ze względu na to, że kategoria służy mi do interpretacji poezji, nie rozwijam teoretycznego zagadnienia przynależności ekfrazy w klasyfikacjach genologicznych - zob. Słownik terminów literackich, pod red. J. Sławińskiego, Wrocław 1998, s. 122.

${ }^{4}$ „Aby dany tekst literacki (wiersz, fragment prozy lub utworu dramatycznego) mógł zostać uznany za ekfrazę, muszą się w nim pojawić wyraźne oznaki metajęzykowe, które bezpośrednio odsyłają do konkretnego dzieła sztuki malarskiej, rzeźbiarskiej lub architektonicznej" - A. Dziadek, Obrazy $i$ wiersze. Z zagadnień interferencji sztuk $w$ polskiej poezji wspótczesnej, Katowice 2004, s. 54.

5 Por. tamże.

${ }^{6}$ „Opis w hypotypozie - w przeciwieństwie do opisu w ekfrazie - nie odnosi się do konkretnego dzieła sztuki, ale raczej pośrednio przywoluje jakiś obraz i narzuca czytelnikowi konieczność ustalenia ścisłych kryteriów pozwalających wskazać w tekście wyznaczniki malarskości bez posługiwania się prostą analogią. Figura ta zdaje się sugerować analogię z jakimś obrazem lub z jakimśs charakterystycznym sposobem obrazowania malarskiego" - tamże, s. 82 .

${ }^{7}$ A. Dziadek, op. cit., s. 16. 
W rozpoznaniu Dziadka pojawiają się jednak dwie tezy, z którymi chciałbym polemizować. Pierwsza, dzielona z Michałem Pawłem Markowskim, głosi, że ekfraza próbuje ponownie uobecnić przedmiot poprzez jego reprezentację, a z drugiej strony zwraca uwagę na sam sposób reprezentowania, czyli retorykę przedstawienia. Wydaje się, że ten dwubiegunowy podział jest zbyt uproszczony. Brakuje w nim, moim zdaniem, jeszcze przynajmniej jednego elementu, gwarantującego wymiar antropologiczny. Otóż ekfraza (i hypotypoza) może być poecie potrzebna nie po to, by uobecnić dzieło czy też dokonać retorycznego gestu mówienia, ale po to, by rozpoznać pracę własnej pamięci, konstruować tożsamość przez narrację.

Pewien sprzeciw wzbudza również przeciwstawienie ekfrazy pojęciu ekfrastyczności. Dziadek pisze:

$\mathrm{Z}$ punktu widzenia współczesności trzeba by [...] mówić o szerokim zjawisku ekfrastyczności, a jedynie w pojedynczych, wybranych tekstach wskazywać pewne cechy właściwe ekfrazie. Wiersz Zbigniewa Herberta Fragment wazy greckiej zdaje się spełniać wszystkie ważniejsze wyznaczniki ekfrazy, a jednak realizuje założenia tej formy tylko połowicznie, bo przeciez nie koncentruje się na samym dziele sztuki, ale wkracza w historię i bez odniesienia do niej pozostaje "niedoczytany" [podkr. moje-M.T.18.

Z tego sposobu myślenia można wyczytać założenie, że istnieje jakaś „czysta ekfraza”, opis pozbawiony elementu interpretacji czy wartościowania. A przecież koncentrowanie się "na samym dziele sztuki” nie jest domeną liryki, lecz raczej historii sztuki. W dalszej części wywodu Dziadek prostuje jednak to złudzenie i powołując się na Riffaterre'a, wprowadza przeciwstawienie „ekfrazy krytycznej” (która może być punktem wyjścia do reprezentacji literackiej) oraz „ekfrazy literackiej”. Chciałbym zatem postawić tezę, tylko częściowo zbieżną z ustaleniami autora Obrazów $i$ wierszy: w przypadku liryki mamy do czynienia wyłącznie z ekfrastycznością, czyli - jak powiedziałby Foucault - niekończącym się poszukiwaniem istoty obrazu. Poszukiwaniem, którego fundament stanowi praca pamięci.

Już sam tytuł tomu Zobaczone sugeruje obieraną przez poetkę strategię kontaktu ze światem, kanał przekazu stanowiący podstawę twórczości słownej. Mówiąc o swoim sposobie patrzenia na świat, Julia Hartwig stwierdza zresztą, że „zobaczyć - to nie jest tylko sprawa oka. Zobaczyć - to znaczy poznać coś do głębi" ${ }^{2}$. Natomiast pytana o zbieżności poezji z malarstwem wyznaje:

8 Tamże, s. 56.

9 J. Hartwig w rozmowie z K. Janowską i P. Mucharskim, Sztuka patrzenia, „Tygodnik Powszechny" 2001, nr 33, s. 4. 
Pamięć jest malarzowi tylko częściowo potrzebna, jak przypuszczam, ponieważ maluje on to, co ma przed sobą lub, w przypadku malarstwa abstrakcyjnego, to, co kreuje, co wydobywa z wlasnej wyobraźni. Podczas kiedy poeta zawsze sięga do pamięci, bo nikt nie pisze patrząc na krajobraz czy na człowieka, ale dopiero wówczas, kiedy jego obraz przywołuje, czasem z głębokiej przeszłości. Zresztą opis nie jest, z pewnością, zadaniem poetyckim. W poezji wszystko polega na przeżyciu, choćby owego krajobrazu, na włożeniu w niego wyobrażeń, które są w nas, które budzą się pod jego wpływem ${ }^{10}$.

Jeśli wierzyć tej deklaracji poetki, opis przeżycia wywołany oglądem obrazu, przypominany po latach, powinien dominować w wierszu nad opisem obrazu. Kiedy jednak czytamy wiersz Uciekajac przed angielska wycieczkq $w$ Orangerie ogladam "Buduar» Matisse'a (który bez wątpienia jest ekfrastyczny), zastanawiamy się nad obecnością elementów refleksji nad własnym doświadczeniem:
Dzień musiał być wtedy letni ledwo dotknięty kolorem
Na stole serweta w pasy i bukiet przywiędłych anemonów
Dwie panie Jedna na wpół skryta za tiulową firanką druga odpoczywająca na leżaku
Wszystko pociągnięte przejrzystą bielą upalnego dnia
kiedy słońce niewidoczne za białym ekranem nieba
pulsuje miękkim upartym tętnem (s. 79).

Opis obrazu jest dość wierny, aby jednak dobrze zrozumieć ekfrastyczność, przyjrzyjmy się najpierw temu, co poetka uwzględnia w swym opisie, a co pomija. Obserwatorka wymienia więc elementy najlepiej widoczne: stół przykryty serwetą i kwiaty w wazonie, kobietę chowającą się za firanką i drugą wypoczywającą w pozycji półleżącej. Rozpościerającą się za oknem biel określa natomiast jako „biały ekran nieba”. W wierszu nie znalazło się miejsce dla dobrze widocznego na obrazie Matisse'a lustra, stojącego na tym samym stole kubka ani dla rosnącego za oknem drzewa. Zwraca uwagę także zupełny brak określeń kolorów (wyjątkiem jest wspomniana wyżej biel), częściowo zastępowanych przez przywołanie warunków pogodowych - letni dzień, upał, słońce „pulsuje upartym tętnem". Zauważone braki są ciekawsze dla interpretacji, gdyż pozwalają pytać o motywy wyboru. Wydaje się, że poetka zauważyła wyłącznie elementy największe, a pominęła mniejsze. Taki wybór ma podwójną motywację. Wynikać może z selektywnej pracy pamięci, w pierwszym rzędzie pozbywającej się informacji najmniej ważnych. Po drugie, poetka „ucieka przed angielską wycieczką" - zatem ogląda obrazy w pośpiechu, nie wnikając w szczegóły, lecz próbując zachować pewien oryginalny, niepowtarzalny klimat. Tytuł ma dla interpretacji tego tekstu ogromne

${ }^{10}$ Tamże. 
znaczenie: wskazuje nie tylko na odniesienie malarskie (bezpośrednie nazwanie obrazu powoduje, że możemy mówić o ekfrazie), ale nadaje wspomnieniu charakter podmiotowy, czyni je opisem osobistym. Przede wszystkim za jego sprawą wiersz zostaje zdynamizowany i możliwa staje się interpretacyjna gra. Poetka ucieka, a jednak zatrzymuje się, by obejrzeć obraz. W tym momencie może solidaryzować się z odpoczywającą na leżaku panią domu, choć równocześnie jest w sytuacji drugiej kobiety, kryjącej się za zasłoną. Solidaryzuje się z nią, nie chce bowiem być oglądana przez grupę turystów, jak narażone są na nieustanne spojrzenia damy $z$ buduaru. Nie bez znaczenia pozostaje również fakt, że kobieta kryjąca się za firanką stoi obok okna ukazującego „biały ekran nieba”. Jest to bowiem miejsce otwarcia przestrzeni obrazu i to ono nadaje tonację emocjonalną - przy czym zachodzi pozorny paradoks, pozwalający kolorowi z palety barw zimnych dawać światło ciepłe, sprawiające wrażenie upału („przejrzysta biel upalnego dnia”). Sprzeczność jest tylko pozorna, czego dowodzą ustalenia optyki: biel widzimy różnie nie tylko w zależności od otaczających ją barw, ale i stopnia "szarości”; odbiór barwy zmienia się też $\mathrm{z}$ wiekiem.

Wydawać by się mogło, że nazwa paryskiego Museé de l'Orangerie pojawia się tu wraz z melancholijną, acz jednorazową reminiscencją. Gdy jednak dokładnie przyjrzymy się wierszom pomieszczonym w tomie Zobaczone, dostrzeżemy, że Uciekajqc przed angielskq wycieczkq... nie jest tekstem osobnym. Przykładem może służyć inna ekfraza - Rozpoznawanie Soutine'a:

Te domy chylące się w jedną stronę

jak gdyby dąl w nie potężny wiatr

domy jak stado pędzonych podmuchem gęsi

drzewa przegięte niewidzialną burzą

dramatycznie

Obok portret cukiernika w białym kitlu

w wysokiej białej czapie

i ministranta w komeżce

Obaj jakby wiatrem wychłostani

niczym wysuszone i pogięte strąki fasoli

Kolekcjoner pan Walter musiał polubic malarstwo Soutine'a

skoro zgromadził tyle jego obrazów w swojej kolekcji

Tego biedaka Soutine'a

nieśmiałego młodzieńca żydowskiego

który zaawanturowal się z Białorusi do Paryża

gdzie według wszelkiego prawdopodobieństwa powinien był zginąć

w tłumie artystów przybyłych $\mathrm{z}$ całego swiata

ale został wziętym i sławnym jeszcze za życia malarzem

zaczął nosić eleganckie futra i kapelusze 
uwiedziony przez szykowny paryski świat od którego tak gwałtownie uciekały

jego natchnione wiatrem obrazy

(Rozpoznawanie Soutine'a)

Wiersz prowokuje serię pytań: dlaczego wybrano Soutine'a? które z jego obrazów zostały opisane? co je łączy prócz „natchnienia wiatrem”? Kluczowe znaczenie ma wers 11 , niezwiązany bezpośrednio z malarzem, znajdujący się dokładnie w połowie tekstu („Kolekcjoner pan Walter musiał polubić malarstwo Soutine'a"). Poszukiwania nazwiska kolekcjonera prowadzi nas bowiem wprost do Muzeum Oranżerii, w którym znajduje się kolekcja Jeana Waltera i Paula Guilleaume'a. Ich imiona dokumentują dwa małżeństwa Juliette Domenici Lacaze - po śmierci pasjonata Guilleaume’a wyszła za mąż za Waltera, multimilionera interesującego się sztuką. Nie bez powodu ta właśnie kolekcja interesuje Hartwig i inspiruje ją do poetyckich wspomnień. Guilleaume, człowiek na co dzień zajmujący się samochodami, znalazł się bowiem w samym sercu paryskiej bohemy, gdy w 1911 roku Apollinaire zainteresował się wystawionymi przez niego $\mathrm{w}$ oknie figurami afrykańskimi. Jeżeli dodać, że artystycznym mentorem był dla niego Max Jacob, a znał również Picassa, Picabię, Chirico, Laurencin czy Modiglianiego, łatwiej zrozumiemy zainteresowanie poetki zebraną przez Guilleaume'a kolekcją.

Powróćmy jednak do samego utworu i jego ekfrastycznych implikacji. Rozpoznawanie Soutine'a przynosi opis nie jednego, lecz aż pięciu obrazów, znajdujących się w Orangerie. „Domy chylące się w jedną stronę" oddają sytuację z obrazu Les Maisons (czyli właśnie „domy”), „domy jak stado pędzonych podmuchem gęsi" notują obserwację Le village (Wioska), „drzewa przegięte niewidzialną burzą" powtarzają jakby tytuł Arbre condé (Pochylone drzewo). Są jeszcze wśród tych pejzaży obrazy „cukiernika w białym kitlu” (Le Petit Pâtisier - Mały cukiernik) oraz „ministranta w komeżce” (Enfant de chœur). Poetka używa zatem chwytu dość rzadkiego w ekfrazie: „obrazowość” jest zawarta już w samych nieznacznie zmodyfikowanych - tytułach. Jak się wydaje, nadrzędnego „bohatera" tego malarstwa upatruje Hartwig w wietrze, poruszającym nie tylko rośliny i ludzi, ale i budowle. Sam Chaïm Soutine jest jakby przepędzany wiatrem z Białorusi do Paryża, choć później, gdy wiatr nadal wieje na jego płótnach, on sam stabilizuje się i jeszcze za życia zyskuje uznanie i sławę. Muzeum Oranżerii, w którym przebywamy wraz z obserwującym podmiotem, ma w swej kolekcji aż 22 płótna tego malarza (tyle też wersów liczy poświęcony mu utwór).

Powtarzam pierwsze $\mathrm{z}$ serii zadanych powyżej pytań: dlaczego wybrano Soutine'a? Czy dlatego, że prezentuje wybitny styl, porusza tema- 
ty, którymi inni gardzą, a może w wyjątkowy sposób operuje światłem? Po trosze prawdy jest pewnie w każdej z tych odpowiedzi, choć ja lokuję powód zainteresowania gdzie indziej. Poetka wybrała Soutine'a - jak sama zdradza swój zamysł w tytule - po to, by go rozpoznawać. Wiersz wyraźnie dzieli się na dwie części: odnoszącą się do obrazu i do biografii artysty. Tymi dwoma torami przebiega też „rozpoznawanie” (pierwszy operuje więc synekdochą, w której Soutine zastępuje swe dzieła, drugi dotyczy go już bezpośrednio). Rozpoznawanie oscyluje zatem między obrazem pewnej rzeczywistości i obrazem człowieka, który tę rzeczywistość percypuje. Jest jeszcze trzeci wymiar, który dopełnia antropologicznego gestu rozpoznania: opiera się on na pracy umysłu obserwującej poetki (i procesach jej pamięci). Silnie obecne ,ja" mówiące sprawia, że mamy do czynienia $\mathrm{z}$ wierszem lirycznym, u którego podstaw znajduje się kontemplacja.

O ważność tego niemodnego dziś terminu upomina się Michael Oakeshott w eseju Poezja $i$ jej głos $w$ rozmowie ludzkości:

W intelektualnej historii Europy kontemplacja, pojmowana jako całkowicie bierne doświadczenie prawdziwych bytów, przez długie stulecia zajmowala najwyższe miejsce w hierarchii ludzkich doświadczeń, podczas gdy badania naukowe uważano w najlepszym razie za wstęp do niej, a praktyczne działanie za coś, co tylko odwraca uwagę. W ostatnich czasach nie tylko pozbawiono kontemplację owej nadrzędnej pozycji [...], ale wręcz zakwestionowano jej zasadnośćc ${ }^{11}$.

Kontemplacji poprzez poezję przeciwstawia Oakeshott dwa inne głosy: nauki (konstytuowany przez „system obrazów koncepcyjnych"12) i działań praktycznych (każdy podmiot zamieszkuje osobny świat i musi konfrontować się z innymi podmiotami13). Sam „głos poezji”, któremu należy przywrócić należne miejsce, określa autor jako „tworzenie pewnego rodzaju obrazów i poruszanie się pośród nich odpowiednio do ich charakteru". Poezja jest tu rozumiana jeszcze szerzej niż w klasycznych ujęciach starożytnych - pod pojęciem tym ukrywają się zarówno pisarstwo, jak i malarstwo, rzeźba oraz muzyka. Dlatego właśnie kontemplacja i zachwyt stają się postulowanym przez Oakeshotta sposobem obcowania ze światem ${ }^{14}$. W kontekście tych rozważań warto poddać interpretacji jeszcze jeden tekst, powstały pod wpływem wizyty w Museé de l'Orangerie - refleksję o stosunku między światem i obrazami:

${ }_{11}$ M. Oakeshott, Poezja jako gtos $w$ rozmowie ludzkości, tłum. L. Sommer, w: tegoż, Wieża Babel $i$ inne eseje, wybór i wstęp P. Śpiewak, Warszawa 1999, s. 266.

12 Tamże, s. 260.

13 Tamże, s. 254.

14 Tamże, s. 263-264. 
Sala muzeum oświetlona dwoma rzędami okien

w oknach widok świata nie namalowanego

równie pociągający jak same obrazy

Z jednej strony Park Tuileryjski

drzewa rozpięte miłośnie na niebie

i sadzawka trzepocząca na wietrze skrzydełkami wody

z drugiej strony Sekwana

Wśród powolnej procesji platanów

płyną spacerowe statki wypełnione turystami

te same statki które wieczorem roziskrzają się jak gwiazdy

rzucając na brzeg wędrujący snop światła

Między tą amfiladą okien i amfiladą obrazów

sam nie wiesz której przyznać pierwszeństwo

Więc najpierw spróbuj tych smakowitych wiśni Renoira

i posłuchaj grającej na fortepianie dziewczynki

której przewraca nuty pochylona nad nią różowozłota siostrzyczka

Nie zapomnij też złożyć życzenia urodzinowe Paulowi

synkowi Picassa

którego z tej okazji przebrano w strój pierrota

(Trudno wybrać)

Hartwig po raz kolejny używa ekfrazy w wersji nieobecnej w polskich opracowaniach i definicjach słownikowych. Pokazuje mianowicie nie pojedynczy obraz, ale serię obrazów czy - jak określa to James Heffernan w tytule swej książki o ekfrazie - „muzeum słów”. Ograniczenie opisów do krótkich, ascetycznych wyrażeń ma na celu zarysowanje lirycznej sytuacji, zbudowanie tła i uczynienie wiarygodnym podmiotowej obecności w konkretnym miejscu. Poetce nie zależy bowiem tylko na obserwacji dzieł sztuki, bo choć docenia ich artyzm, chce przede wszystkim zanotować swoje przeżycie. Okazję do tego znajduje właśnie w konfrontacji świata „namalowanego” i „nienamalowanego”, prawdziwości parku i sztuczności obrazu. Zauważmy jednak, że prawdziwość zostaje ujęta w szereg cudzysłowów, w wyznaniu ukazuje się jej aporetyczna natura. Ograniczają ją bowiem ramy okienne - widzimy więc tylko fragment rzeczywistości i zdajemy sobie sprawę, że całość nigdy nie będzie dla nas dostępna. Ponadto nasze oczy podlegają złudzeniom, wynikającym ze zmian światła - w wierszu trudność wyboru wzmaga między innymi fakt, że salę oświetla światło dzienne w nocy zamieniane na „wędrujący snop światła” sztucznego. Statyczna jasność dnia (której źródłem jest jednak dynamiczny ruch słońca) zostaje zamieniona na dynamiczny (choć punktowy) ruch latarni statku. Ostatnią „ramę” prawdziwości stanowią natomiast słowa: próba „przyznania pierwszeństwa” obrazom malarskim lub widzianym z okna muzeum ma przecież charakter językowy. Widzimy inaczej dzięki słowom, tak samo jak zmieniamy swe ro- 
zumienie dzięki obrazom - są to wartości nierozłączne ${ }^{15}$. Konkluzja ta jeszcze raz udowadnia, że porządki natury i kultury niesłusznie były polaryzowane $w$ badaniach antropologicznych, a ich ponowne złączenie jest jak najbardziej uzasadnione.

Oprócz swoistej techniki opisu muzeum Trudno wybrać przynosi ciekawy przyczynek do rozważań nad postrzeganiem i pracą pamięci. Ekfrazy, które znajdują się w wierszu, dodają jeszcze jeden element do serii zmyśleń powstałych „między [...] amfiladą okien i amfiladą obrazów". Gdy bowiem uważnie prześledzimy katalog stałej wystawy Waltera i Guilleaume'a przekonamy się, że nie ma w nim malowanych przez Renoira wiśni (lecz poziomki), na fortepianie gra złotowłosa dziewczynka, ale kartki przewraca brunetka, natomiast za pierrota został przebrany Claude, syn Renoira (co prawda, Picasso malował swego syna Paula w stroju harlequina, jednak obraz znajduje się w innym paryskim muzeum). Co oznacza ta wyraźna „komedia pomyłek” ze strony opowiadającego podmiotu? Potwierdza przede wszystkim nieciągłość pamięci i jej konstrukcyjne dążenia - tytułowe wyrażenie „trudno wybrać” nie oddaje wyłącznie dylematu związanego $\mathrm{z}$ przebywaniem $\mathrm{w}$ muzeum lub poza nim, lecz stawia fundamentalne pytanie o rodzaj prawdy (prawdziwości), przekazywanej przez sztukę i pamięć.

Zobaczone jawi się na podstawie powyższych rozważań jako tom zaświadczający przekonanie poetki o ścisłym przyleganiu rzeczywistości i jej wizualizacji, pamięci i jej reprezentacji. Seria tekstów o Muzeum Orangerie, a także następny wiersz, któremu się przyjrzymy - Ortowo pod Leiden - pozwalają na wysunięcie jeszcze jednej tezy, niespotykanej w polskiej nauce o literaturze. Ekfrazę można bowiem, moim zdaniem, połączyć z prężnie rozwijającą się w ramach antropologicznych badań nad tekstami poetyką przestrzeni16. U Hartwig nie będziemy oglądać

15 Donald Davidson doprowadza tę tezę do ostateczności, gdy proponuje zniesienie tradycyjnego myślenia o języku jako narzędziu. Język, przekonuje badacz, nie różni się w znaczący sposób od zmysłów, gdyż - tak jak one - jest zależny od wyspecjalizowanych funkcji mózgu. Skoro zatem widzimy oczyma, powinniśmy mówić o postrzeganiu świata dzięki temu, że mówimy językiem, który staje się możliwą do wyuczenia funkcją komunikacyjną, przeksztalconą w percepcję. Przestaje natomiast oznaczać filtr, zapewniający umysłowi opis fragmentu rzeczywistości. „Zdolność mówienia, postrzegania i myślenia rozwijają się stopniowo razem”. Por. D. Davidson, Widzieć poprzez język, „Teksty Dru-

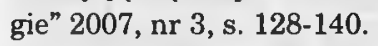

16 Poetykę przestrzeni dokumentują - z różnych perspektyw - m.in.: Ewa Rewers (E. Rewers, Post-polis. Wstęp do filozofii ponowoczesnego miasta, Kraków 2005) i Elżbieta Rybicka (E. Rybicka, Modernizowanie miasta. Zarys problematyki urbanistycznej $w$ nowoczesnej literaturze polskiej, Kraków 2003). Rewers w jednym z rozdziałów swej rozprawy wiąże miasto $\mathrm{z}$ pamięcią, dostrzegając trzy własności dyskursów pamięci nowoczesnej: a. rozmnożenie strategii pamięci, jej modeli i praktyk; b. przejście od pamięci jako 
tego zjawiska w skali makro - spotkamy się z przestrzenią, którą wciąż się oswaja, bardzo często przy użyciu obrazu. Bywa, że owe „miejsca pamięci" (klasyczny termin Pierre'a Nora) mają znaczenie jednostkowe o zabarwieniu sentymentalnym, malarski pejzaż uwzniośla je i każe szukać znaczeń dodatkowych, ważnych też dla pamięci zbiorowej:

Białe niebo sierpniowe, białe chmury, białe.
Jak weramon kojąca ta białość sierpniowa.
Po szumnej fali nocy i po mew szaleństwie
spod bezsennej powieki patrzy z góry niebo.
Pachnie powietrze słone zapuchłe od płaczu
i jakaś postać drobna w chustkę otulona
wznosi ku morzu rękę patetycznym gestem.
Idą do sieci ryby mlekiem mgły opite
i białe kwiaty meduz rozkwitłe o świcie.
Pejzaż mój stoi martwy jak po bitwie morskiej
i jeszcze zapach prochu nad falą się niesie.
Pejzaż ten van de Velde przysłał mi w prezencie
w dniu kiedy żaden inny nie byłby prawdziwszy.

(Ortowo pod Leiden)

Poetycki pejzaż malowany z natury (Orłowo) i z obrazu (któregoś z licznych holenderskich malarzy pejzażystów o nazwisku van de Velde) ma paradoksalny charakter. Jest nie tylko rzutowaniem wspomnienia na niezwiązaną $\mathrm{z}$ nim $\mathrm{w}$ żaden sposób reprezentację twórczą, ale łączy w sobie przeciwstawne plany: harmonii i dysharmonii, zgody na świat i rozczarowania. Przywołane sprzeczności dobrze korespondują z tytułowym konceptem „przeniesienia” polskiego Orłowa pod holenderską Lejdę. Pejzaż staje się pretekstem do rozważań o przestrzeni uniwersalnej, której nie można rozpoznać bez pośredniczącej roli towarzyszącej mu kultury i języka. Skojarzenie poetki wynika z dekontekstualizacji obrazu, czyli uczynienia go przedmiotem opisu wtórnego, niezgodnego z pierwotną intencją autorską.

Ekfraza zyskuje jeszcze jedną funkcję, wykorzystywaną w badaniach psychologicznych, a tu transponowaną na język poetycki. Stanowi bowiem metodę badania uczuć $i$ emocji, które nie są immanentnie wpisane w obraz, lecz powstają (lub są wzmacniane) w jego odbiorze. Kiedy bowiem poetka pisze o kojącej białości czy bezsennej powiece nieba, wówczas $w$ gruncie rzeczy przykrawa poetycki opis do własnego doświadczenia (co w warstwie stylistyczno-językowej potwierdzają przede wszystkim przymiotniki). Psychologiczne wyposażenie ekfrazy mogło-

doświadczenia egzystencjalnego do pamięci jako doświadczenia kulturowego oraz c. pamięć jako doświadczenie kulturowe badane w perspektywie transkulturowej (s. 181). 
by opierać się na rozróżnieniu wyobrażeń odtwórczych (ejdetycznych) i twórczych. Te pierwsze związane są z oglądem i deskrypcją, pozwalającą wyobraźni stworzyć plastyczną wizję przedstawianego przedmiotu. Wyobrażenia ejdetyczne są stosunkowo trwałymi obrazami, o których można z dużą szczegółowością opowiedzieć - nawet po pewnym czasie od ich obejrzenia. Co ciekawe, stabilizacja obrazu w pamięci ma charakter językowy, a większą aktywność w obrazowaniu ejdetycznym wykazują dzieci17. Powyższe badania mogą prowadzić do konstatacji o sytuowaniu liryki pomiędzy utrwalonym odwzorowaniem widoku a otwartym systemem językowym, poszukującym drogi między kliszami komunikacyjny$\mathrm{mi}$ a oryginalnym, indywidualnym sposobem konstruowania wypowiedzi. Liryka poszukuje ich, oczywiście, z twórczą samoświadomością, dlatego jej działania sytuują się już w drugim typie wyobrażeń, będących „efektem intencjonalnych działań podmiotu"18, czyli wyobrażeń twórczych $^{19}$. Z czasem sama psychologia uznała podział za nieostry, wprowadzając w miejsce statycznego systemu model dynamiczny. Ulric Neisser, autor teorii postrzegania jako procesu cyklicznego, przekonuje, że proces pamięciowy sprzęga następujące po sobie etapy: korzystanie $\mathrm{z}$ dostępnych danych, modyfikowanie schematów pamięciowych przy wykorzystaniu tych danych oraz wprowadzanie nowych informacji (które przechodzą tę samą drogę).

W tym kontekście można dokonać ciekawego odczytania finalnej części utworu Hartwig. Wers „Pejzaż mój stoi martwy jak po bitwie morskiej" odnieść bowiem można do sfery wizualnej, zapamiętanego obrazu, który jest wydobywany z pamięci (ale na zasadzie wyobrażenia odtwórczego). Inna interpretacja prowadzi nas ku lekturze pozornie negatywnej, odsłaniającej niemożliwość werbalizacji obrazu (zatem i osiągnięcia fazy ejdetycznej). Skoro jednak podmiot jest przekonany o niemożliwości odtwarzania, a tym samym niewystarczalności pamięci - wchodzi na drogę wyobrażenia twórczego. Martwy pejzaż po bitwie zostaje uzupełniony o daną zmysłową w postaci zapachu prochu, który ożywia scenę i pozwala ją pamiętać jako osobiście przeżytą. W ostatnim wersie autorka stawia natomiast kwestię prawdziwości obrazu („w dniu kiedy żaden inny nie byłby prawdziwszy"). Tym samym dokonuje ekstrapolacji włas-

17 E. Zdankiewicz-Ścigała, T. Maruszewski, Wyobrazenia jako pierwsza forma doświadczenia generowanego przez jednostkę, w: Psychologia. Podręcznik akademicki, pod red. J. Strelaua, t. 2: Psychologia ogólna, Gdańsk 2004, s. 186.

18 Tamże, s. 187.

19 Zastanawiający wydaje się fakt, ze autorzy opracowania jako jedną z głównych przyczyn uruchamiania wyobrażeń twórczych podają ograniczony zasób pamięciowy. Wyobraźnię traktuje się w tej koncepcji instrumentalnie, czyniąc z niej narzędzie do wypełniania pustych miejsc i rekonstruowania obiektów. Por. tamże. 
nych uczuć, a także znaków przynależnych dziełu malarskiemu na wspólną płaszczyznę wyobrażeń, pełniącą funkcję na poły terapeutyczną. Jeżeli bowiem uczucia zmieniają się pod wpływem natury i jej odwzorowań, to same odwzorowania możemy uważać za odnoszące się do prawdy (przy całej niejednoznaczności pojęcia we współczesnym dyskursie nauk humanistycznych).

U autorki Zobaczonego znajdziemy także inne ekfrazy - poetyckie opisy fotografii występujące w funkcji zmodernizowanych obrazów. Hartwig nie zapomina przy tym nigdy o antropocentryzmie wizji, o człowieku, który kryje się za danym znakiem:

Państwo Lutosławscy jedzą gruszki na Rialto
Państwo Lutosławscy jedli gruszki przed hotelem
kiedy mijaliśmy ich w słońcu
w złotym kurzu wzniesionym przez tłum
święcący triumfalnie swój podbój Wenecji
Ach ten rudy lok spadający na czoło wiolonczelistce
zatopionej w miłosnym akcie z wiolonczelą
te jej okrągłe rozsunięte kolana
Syreny unosiły się na białych plecach vaporetto
sunące z rozwiniętymi sztandarami szumu
ujarzmione krańce wód chlupotały o omszałe stopy domów
i niebem płynęły obłoki Tintoretta
A mgła zaczajona w samym sercu blasku
czekała cierpliwie na wieczór
by przemienić w zjawę
monstrancję kościoła Santa Maria della Salute

(Fotografia $z$ pamięci, $Z$, s. 41)

Fotografia $z$ pamięci - jak tytułuje wiersz poetka - naśladuje technikę zatrzymanego na kliszy obrazu tylko w warstwie najbardziej dosłownej. Istota tekstu leży jednak w przeplataniu wrażeń muzycznych i malarskich, z których pierwsze (jako niesemantyczne) bywają domeną zapomnienia, drugie zaś funkcjonują zwykle jako dokument pamięci. Tym razem poetka wybiera jednak ze sztuki zjawiska ulotne: syreny w weneckim tramwaju wodnym (vaporetto), chmury z obrazów Tintoretta (znajdujących się m.in. w weneckiej bazylice Santa Maria della Salute), a także mgłę - jakby chcąc pokazać, że klucz do pamięci nie musi być konstrukcją trwałą i empirycznie sprawdzalną. Rialto, najsłynniejszy most $\mathrm{w}$ mieście, otrzymuje dzięki tym zabiegom pocztówkę nieledwie symboliczną. Obserwacja państwa Lutosławskich, uwiecznionych właśnie na Rialto, łączy się z przypomnieniem patronki bazyliki św. Maryi niespodziewanym szczegółem. Otóż malarze weneccy często łączyli motyw maryjny $\mathrm{z}$ gruszką, symbolizującą wyjątkową więź matki z synem.

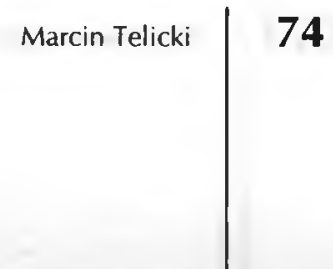


Sądzę, że samo wprowadzenie tego motywu sakralizuje przestrzeń miasta i mityzuje przeszłość. Obraz Wenecji staje się, zgodnie z tytułem wiersza, fotografią rekonstruowaną z pamięci, a nie z „rzeczywistości”. Bowiem między tym, co funkcjonuje we wspomnieniu, a tym, co zwykło się uważać za rzeczywiste i prawdziwe, nie zachodzi sprzeczność. Joanna Tokarska-Bakir tłumaczy, że grecka aletheia (nieskryta prawda) ma wspólny rdzeń z lethe (zapomnieniem):

Wbrew oczekiwaniom płynącym $\mathrm{z}$ etymologii $[\ldots]$ lethe wcale nie zaprzecza prawdzie. W tym rozumieniu prawdy, które Heidegger rozpoznaje u Greków, lethe, skrywanie, należy do istoty prawdy. To, co skryte, ruch zstępujący, niewidzialnie pracuje nad tym, co wychodząc na jaw, ostatecznie ukaże się oczom ${ }^{20}$.

Aletheia i lethe łączą się w medium nowoczesnym fotografii, a poetka podkreśla jeszcze to zespolenie przez zastąpienie konstrukcji czasu teraźniejszego (,jedzą") czasem przeszłym (,jedli”) w drugim wersie. Technikę zastąpienia można by nazwać - korzystając $\mathrm{z}$ doświadczenia języków starożytnych - praesens historicum, doskonale oddaje bowiem aktualizowanie przeszłości (analogicznie do techniki fotograficznej), unaoczniając jej elementy i niwelując dystans temporalny ${ }^{21}$. Warto podkreślić analogie między zabiegiem językowym a fotograficzną reprezentacją: splatają się $\mathrm{w}$ nich dwa sposoby widzenia świata (przeżywany i zapamiętany, a więc teraźniejszy i przeszły), szczególną rangę zyskuje zaś obserwacja i tworzone przez nią iluzje rzeczywistości. Lektura wiersza Fotografia $z$ pamięci skłania zatem do zadania istotnych pytań o naturę przeżycia ludzkiego, skoro przyswajaniu go towarzyszy tak wielu pośredników: obserwacja, świadomość i pamięć, a także fotografia, muzyka i język. Nie sposób rozważyć powyższych kategorii bez zaplecza kulturowo-filozoficznego $\mathrm{z}$ różnorodną $\mathrm{i}$ bogatą wielowiekową tradycją (z przyczyn oczywistych wyłączając fotografię, choć część rozważań nad nią byłaby zbieżna $\mathrm{z}$ refleksją nad obrazem). W tym miejscu powiem tylko, że dokonywanemu przez autorkę Zobaczonego namysłowi nad światem z pewnością towarzyszy Platońska droga "do wewnątrz" (reditus in se ipsum), która myśleniu - a więc i pamięci, będącej jego komponentem - „przypisuje zdolność ujmowania czegoś rzeczywistego za pomocą intuicji"22.

${ }^{20} \mathrm{~J}$. Tokarska-Bakir, Obraz osobliwy. Hermeneutyczna lektura źródel etnograficznych - wielkie opowieści, Kraków 2000, s. 382.

${ }^{21}$ Co ciekawe, niektóre języki dokonaly znamiennego rozstrzygnięcia w sposobie opisu fotografii. Np. po angielsku opowiadanie unaoczniające prowadzi się w czasie teraźniejszym dotyczącym czynności trwających w chwili mówienia o nich (present continuous).

22 Filozofia. Podstawowe pytania, pod red. E. Martensa i H. Schnaedelbacha, przeł. K. Krzemieniowa, Warszawa 1995, s. 78. Notabene jest to, być może, droga całej antropologii poetyckiej, prowadzącej swe poszukiwania nie metodą pozytywistycznych modeli 
W Zobaczonym Hartwig umieściła również specyficzną antyekfrazę napisany pod wpływem doświadczenia amerykańskiego wiersz Próba:
W Parku Brooklińskim przy roślinach i kwiatach
tabliczki z nazwami zapisane systemem Braille'a
Dla niewidomych
Spróbuj zamknąć oczy Spróbuj pomyśleć jak to jest
znać tylko tabliczkę z napisem
Chwytasz zapach i czytasz dłońmi nazwę
Masz wyobrazić sobie kwiat
Wyobrazić go sobie według jego nazwy
może towarzyszy ci ktoś zaprzyjaźniony
kto opowie ci kwiat
Podziwiam dokładność jego opisu:
kształt ilość platków wielkość układu korony
wysokość lodygi forma liścia Opis doskonaly
A przecież kwiat opisać można tylko kwiatem
Próbuje tego poeta
Również dla tych którzy patrząc nie widzą

(Próba)

Poetka prowokuje powyższym wierszem do dyskusji na dwa zasadnicze tematy: pierwszym z nich jest konstrukcja obrazu bez udziału wzroku (problem wyobraźni), drugim - istota nowoczesnego doświadczenia człowieka. Próba, o której wykonanie upomina się poetka, może prowadzić do ujawnienia związków między naturą wyobrażenia (obrazu) a językiem poetyckim. Tradycyjne ujęcie reprezentacji, proponowane $n p$. przez Gastona Bachelarda w jego projekcie fenomenologii obrazu poetyckiego, nie znajduje tu zastosowania. Jeżeli bowiem uznamy za autorem Poetyki marzenia, że fenomenologia została stworzona przez „czystą, pozbawioną jakiegokolwiek kulturowego czy historycznego zakotwiczenia wyobraźnię" ${ }^{23}$, to figura niewidomego zostanie pozbawiona tradycyjnego utożsamienia $\mathrm{z}$ mędrcem (ale i poetą), postacią wyposażoną w wiedzę niedostępną ogółowi. Obraz nie jest bowiem tylko pochodną recepcji wzrokowej, ale i - nawet w przypadku osób widzących - funkcją językową. Przechodzień w Parku Brooklińskim poznający świat za pomocą tabliczek z napisami w alfabecie Braille'a jest skazany na wieczne zapośredniczenie swojego poznania (a tym samym swojej wyobraźni, we-

i schematów, ale poprzez analizę poszczególnych przypadków. Por. R. Nycz, Antropologia literatury - kulturowa teoria literatury - poetyka doświadczenia, referat wygłoszony podczas konferencji Jaka antropologia literatury jest dzisiaj możliwa?, Poznań 21.-22.05. 2007 r.

${ }^{23}$ A. Burzyńska, M.P. Markowski, Teorie literatury XX wieku. Podręcznik, Kraków 2006, s. 95. 
wnętrznego obrazu). Nie jest ono nigdy czyste, ale zawsze uprzedzone przez formę słowną - opis. Ekfraza, którą tworzy osoba opowiadająca, zyskuje w tym wymiarze charakter paradoksalny: zawsze jest poza rzeczywistością (widzialną), a jednocześnie nigdy jej nie opuszcza ${ }^{24}$. Równocześnie staje się - jak to nazwałem wcześniej - antyekfrazą, gdyż nie pozwala odbiorcy komunikatu skonfrontować wypowiedzi z rzeczywistością, do jakiej się ona odnosi (co jest przecież podstawowym warunkiem ekfrazy).

Wyobrażenie sobie kwiatu „według jego nazwy" (przez kogoś, kto "opowie ci kwiat”) zamiast „opisania kwiatu kwiatem” wskazuje na szereg problemów doświadczenia nowoczesnego. Pytamy więc nie tylko o czasowość, ale i bezpośredniość doświadczenia, a także o przedwstępne założenia, z którymi przystępujemy do rzeczywistości. Ryszard Nycz wyróżnia trzy znaczenia, w jakich rozumieć można nowoczesność jako doświadczenie. Nazywa je kolejno: doświadczeniową nowoczesnością, doświadczeniem nowoczesności i doświadczeniem nowoczesnym. W tym ostatnim świat nie jest doświadczany jako projekt, ale

poprzez urzeczywistniające się $\mathrm{w}$ toku realizacji owego modernizacyjnego projektu zmienne formy życia społecznego i indywidualnego, cywilizacyjne pejzaże, technologicznie przekształcone środowisko oraz kulturowo i społecznie wymodelowaną przyrodę. Doświadczenie to rodzi się [...] w doznaniu chwili, bezpośredniości bycia tu i teraz, poczuciu zanurzenia w nieprzerwanym przeplywie zdarzeń (prowadzącym nierzadko do depersonalizacji)"25.

Z szeroką perspektywą, nakreśloną przez temat wyobraźni i recepcji świata przez ludzi niewidomych, zderza się chwilowość i pozorna nieważność codzienności. Zauważmy, że punktem wyjścia do rozległych rozważań czyni poetka kwiat, o którym nie wiemy nic (włącznie z nazwą). Istotniejszy dla poetki staje się jednak kulturowy filtr, dzięki któremu poznajemy naturę, owa „kulturowo wymodelowana przyroda”. Dla poetki obserwowana sytuacja wypełniająca jednostkowe przeżycie staje się

${ }^{24} \mathrm{~W}$ ten sposób zniesiony zostaje jeden z aspektów przeciwstawienia obrazu i przypomnienia, o którym pisze Ricoeur: „Jeśli wspomnienie jest [...] obrazem (image), to posiada wymiar pozycyjny, co z tego punktu widzenia zbliża je do spostrzeżenia. W innym języku, który adaptuję, powiemy o przeszłościowości bycia wspominanym, ostatecznym odniesieniu aktu wspomnienia. Na pierwszy plan wobec tego, z fenomenologicznego punktu widzenia, wysunie się cięcie między tym, co rzeczywiste, a tym, co nierzeczywiste (teraźniejsze, przeszłe lub przyszłe). O ile wyobraźnia może igrać fikcyjnymi bytami, gdyż nie zależy od rzeczywistości, a ją opuszcza, o tyle przypomnienie ustanawia rzeczy należące do przeszlości. P. Ricoeur, op. cit., s. 67.

${ }^{25} \mathrm{R}$. Nycz, O nowoczesności jako doświadczeniu, w: Nowoczesność jako doświadczenie, pod red. R. Nycza i A. Zeidler-Janiszewskiej, Kraków 2006, s. 10-11.

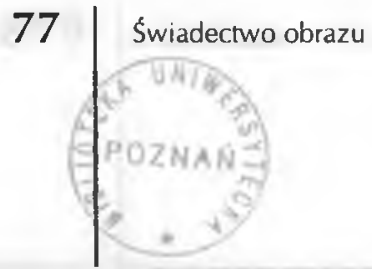


przyczynkiem do rozważań o sytuacji drugiego człowieka, jego procesów poznawczych i sposobów obcowania z rzeczywistością (którego jedynym realnym pasem transmisyjnym jest nie obraz, lecz zapach).

W finale wiersza Hartwig czyni jeszcze liryczną woltę, zamykając go autotematycznym namysłem o poezji: „Próbuje tego poeta/ Również dla tych którzy patrząc nie widzą". Pisanie staje się więc aktem ocalającym obraz od niezrozumienia i zapomnienia, ale i wciąż ponawianym aktem kulturowego zawłaszczania natury. Funkcją poety $w$ świecie nie jest bowiem tworzenie pięknych zdań czy konstruowanie wielopiętrowych metafor, lecz objaśnianie świata tak, jak objaśnia się obrazy i ich historię. Adekwatnym terminem do opisu zjawiska wydaje się hermeneia, traktująca tekst kultury jako tekst święty ${ }^{26}$, nie tylko w znaczeniu wąskim. Hermeneia zaciera różnicę między tekstem sakralnym i świeckim, odnajdując sacrum tekstu w wartościach ogólnoludzkich lub charakterystycznych dla wybranych wspólnot kulturowych (np. europejskiej). Hermeneia jako czytanie tak pojętego świętego obrazu jest również strażniczką pamięci, przede wszystkim zaś - jak pisze Maria Janion -

powolana jest do tego, by nie dopuszczać do zmiany struktury tradycji, do jej deformacji, by utrzymywać tradycję przy życiu, by bronić uniwersalnych znaczeń europejskich, by powtarzać i dowodzić, że np. slowo «ludzkość zawsze znaczyło to samo w tradycji europejskiej, że nie można go dowolnie ksztaltować i wypaczać - gdyż może się to odbyć tylko za cenę odstąpienia i od słowa, i od ludzkości samej ${ }^{27}$.

Wzniosła rola, jaką Janion przypisuje hermeneucie (nie tylko odbiorcy dzieła sztuki, ale i samemu twórcy), nie polega jednak wyłącznie na prowadzeniu nadzoru i rozliczaniu się $\mathrm{z}$ obowiązków wobec pamięci zbiorowej. Zamykając swój znany esej, autorka podkreśla bowiem, że „hermeneuta to taki pilnujący skarbca tekstów strażnik, który musi też ciągle sprawdzać, czy skarby jego nie zaśniedziały, czy wartości nie zastygły w dogmaty"28. Ekfraza może być w świetle tej tezy swego rodzaju punktem kontrolnym hermeneutyki - statyczny i zamknięty w historycznym czasie obraz jest przekładany na aktualny (lub aktualny w innym momencie historii) opis. Implikacje wynikające $\mathrm{z}$ różnicy czasowej między ich powstaniem prowadzą do opisania mechanizmów pamięci, która konstytuuje się jako względnie stała struktura (i w tym sensie współtworzy

${ }^{26}$ Wykład topiki biblijnej i porady dla malarzy dzieł sakralnych przedstawia np. Dionizjusz z Furny w dziele Hermeneia, czyli objaśnianie sztuki malarskiej, tlum. I. Kania, red. i wstęp M. Smorąg-Różycka, Kraków 2003.

${ }_{27}$ M. Janion, Hermeneutyka, w: taż, Humanistyka: poznanie i terapia, Warszawa 1982 , s. 135.

28 Tamże. 
tradycję), ale poddawać ją trzeba ciągłej rewizji (gdyż absolutyzacja struktury łatwo przeradza się w manipulację tradycją). Julia Hartwig czyni to choćby w wierszu Nagana, w którym opatruje pamięć szeregiem pejoratywnych epitetów: niedolężna, opustoszona, niewierna, samowolna, podstępna. Tekst poetycki staje się hipostazą dzięki zastosowanej personifikacji. Ten sam środek stylistyczny sprawia, że wypowiedź przeksztalca się w dialog nierównoważnych partnerów (choć bez ustalonej strony dominującej: poeta ma władzę nad czasem i daje mu naganę, jednak to czas czyni poetę zależnym od siebie).

Chciałbym podkreślić jeszcze jeden charakterystyczny rys „pamięciowego" nurtu poezji Julii Hartwig. Poetka rzadko dokonuje waloryzacji pamięci, godzi się z faktem, iż pewne fragmenty doświadczenia muszą ulec zapomnieniu, co paradoksalnie - jak w wierszu Bez słowa - może nieść za sobą pożytek (przynajmniej indywidualny):

Czyż nie jest natręctwem wobec innych spiewać swoją pieśń

Idź albo giń - mówi wszystko dokoła

Ofiara tysiąckrotnie spełnia się na próżno

bo zapomniana została formuła ofiarowania

i nie jeden największą pociechę znajduje dziśs w tym

że odchodząc - zniknie bez śladu $(Z, \mathrm{~s} .11)$.

Tytułowe „bez słowa” oznacza także „bez śladu”, co nie stanowiąc już elementu opisu ekfrastycznego, odsyła jednak do obrazowości, która staje się darem dla innego oraz darem dla przyszłości. Właśnie za pojęciem daru skrywa się duża część refleksji Hartwig o pamięci i niepamięci. Przypomnijmy, że klasycznym już tekstem analizującym problematykę ofiarowania i przyjmowania prezentów jest opublikowany w latach 20. XX wieku przez Marcela Maussa Esej o darze. Znany antropolog stawia w nim tezę, że w kulturach plemiennych niemal nieznane bylo pojęcie podarunku bezinteresownego, bowiem każda ofiara jest obwarowana nakazami wzajemności, wdzięczności lub współzawodnictwa ${ }^{29}$. Autorka Zobaczonego notuje doświadczenie pamięci niewykraczającej poza ramy jednostkowej egzystencji. Wedlug jej diagnozy społeczeństwo zatomizowało się, co prowadzi do przeobrażenia procesu wymian (także w obszarze pamięci) odróżniających się od tradycyjnych form świata zachodniego czy nawet Maussowskiego „potlaczu”. W tej ostatniej bowiem

${ }^{29}$ Mauss wymienia różnorodne formy darów, m.in. świadczenia całościowe, „potlacz”, dobra kobiece i męskie, a także opisuje rządzącą nimi filozofię ducha rzeczy danej (hau taonga). Por. M. Mauss, Szkic o darze. Forma i podstawa wymiany w spoleczeństwach archaicznych, tłum. K. Pomian, w: tegoż, Socjologia $i$ antropologia, Warszawa 1973, s. $216-219$ i n. 
każda własność plemienna włączana była w obieg świadczeń wzajemnych, jednak nie na zasadzie dobrodziejstwa czynionego drugiemu, ale przez stwarzanie antagonizmów, a nawet prowokowanie wojen (choć w ostatecznym rachunku i one miały służyć wzbogaceniu wspólnoty). Współcześnie formy podarunków przybierają postać mniej angażującą obdarowanego, lecz są także pozbawione wymiaru wspólnotowego („nie jeden największą pociechę znajduje dziś w tym/ że odchodząc - zniknie bez śladu"). Wiersz Bez stowa okazuje się w tej perspektywie tekstem o erozji pamięci jako podarunku, schedy, z której przekazywaniem łączą się określone prawa i obowiązki. Niepamięć ukazuje tu swoją proteuszową naturę $-\mathrm{z}$ jednej strony staje się wybawieniem od niepokojów, z drugiej jednak nie pozwala budować tożsamości grupowej, gdyż nie wskazuje punktów wspólnych (nie bez znaczenia jest tu skojarzenie z loci communes - toposami, „miejscami” stanowiącymi ogniwa pamięci kultury ${ }^{30}$ ).

Pewien rodzaj „natręctwa” w śpiewaniu swej pieśni (w otwierającym wiersz pytaniu retorycznym) i zniknięcie bez śladu (w wersie finalnym) naprowadzają również na trop myślenia o pamięci/ niepamięci w przypominanych przez Michała Pawła Markowskiego kategoriach wymiany charakteryzującej reprezentację:

Reprezentacja [...] to coś pośredniego między zmysłowym kształtem (znakiem, przedmiotem, towarem) a umysłem; ogólny ekwiwalent tego, co szczególowe, wspólna miara, dzięki której możliwa jest wymiana: zarówno myśli, jak i dóbr materialnych. [...] Z tego właśnie powodu kategoria reprezentacji, która jest nadrzędną kategorią wszędzie tam, gdzie pojawia się ekwiwalentyzacja [...], jest przede wszystkim kategorią ekonomiczną. Dotyczy każdej wymiany w obrębie kultury: rzeczy na znaki, znaków na znaki, znaków na znaczenia, znaczeń na znaczenia i dlatego jest obiektem pierwszorzędnego zainteresowania teoretyków kultury ${ }^{31}$.

W kontekście wiersza i wywołanego nim szerszego kręgu problemów mnemonicznych nietrudno nazwać pamięć ekwiwalentyzacją czy wymianą między teraźniejszością a przeszłością ${ }^{32}$. Trudniej - i tu spierałbym

${ }^{30}$ Por. F. Yates, op. cit., s. 44.

31 M.P. Markowski, O reprezentacji, w: Kulturowa teoria literatury. Gtówne pojęcia i problemy, pod red. M.P. Markowskiego i R. Nycza, Kraków 2006, s. 301.

32 Ekonomiczną wartość tej wymiany rzeczywiście można dostrzec w niektórych psychologicznych opracowaniach, poruszających problem pamięci. Np. Tomasz Maruszewski pisze: „Zjawisko inflacji wyobraźni polega na tym, że ludzie, wyobrażając sobie pewne zdarzenia, podwyższają subiektywną pewność ich wystąpienia. [...] Dzięki temu zaczynają tworzyć hipotetyczny obraz pewnej przeszłej sytuacji, nasycony wieloma elementami percepcyjnymi. Obraz ten może stać się rzeczywistością" - T. Maruszewski, Pamięć autobiograficzna, Gdańsk 2005, s. 108. 
się z Markowskim - umiejscowić w tej klasyfikacji zapomnienie, któremu nie sposób odebrać poczesnego miejsca w refleksji o kulturze. Wśród wyliczonych przez Markowskiego wymian między rzeczami, znakami a znaczeniami niepamięć sytuowałaby się w grupie znaczeń, doprawdy, niedających się jednak rozpisać na wartości ekonomiczne. Jest raczej tak, że ów brak pamięci, wycofanie pewnego obszaru poza aktualny namysł nad rzeczywistością paradoksalnie rozszerza perspektywę, ale nie sprowadza się do dążenia (o genealogii ekonomicznej właśnie) typu „idź albo giń". Skoro padło tu nazwisko krakowskiego badacza, warto zaznaczyć, że w jednym ze swoich „błysków” Hartwig polemizuje z Markowskim bezpośrednio, pisząc:

Michał Paweł Markowski w swojej książce Występek. Eseje o pisaniu i czytaniu zamyka fragment rozumowania Barthes'a zdaniem: „Zycie możliwe jest dzięki zapomnieniu, a nie pamięci". Wszystko, co piszę i wyznaję, jest zaprzeczeniem tego stwierdzenia ( $Z i B$, s. 56).

To swoiste credo twórczości należałoby, z punktu widzenia uważnego czytelnika, poddać pewnej weryfikacji. To prawda, że pamięć jest dla autorki Pożegnań "sprawą pierwszej wagi”, jednak - czego dowodzi choćby wiersz Bez stowa - Hartwig dopuszcza również „zniknięcie bez śladu”, zapomnienie $^{33}$. Sądzę zatem, że spór przebiega tu nie na linii pamięci i zapomnienia, ale niemożliwości pamiętania przeciwstawionej maskowaniu niepamięci. Kiedy poetka mówi, że życie możliwe jest dzięki pamięci, rozumie przez to nie tylko pamięć własną, indywidualną, lecz przede wszystkim - pamięć kulturową, system przypomnień, wpisujących własne doświadczenie człowieka w obraz zuniwersalizowanej przeszłości, możliwej do interpretacji przez określoną wspólnotę.

Właściwości ekfrazy splecionej z pamięcią opiszmy na koniec metaforą, użytą w wykładzie Czesława Miłosza, poety niezwykle cenionego przez Julię Hartwig, wygłoszonym podczas odbierania Literackiej Nagrody Nobla:

Tak więc dwa atrybuty poety: chciwość oczu i chęć opisu. Ktokolwiek jednak pojmuje poezję jako „widzieć i opisywać”, musi być świadomy, że wkracza w poważny spór z nowoczesnością zafascynowaną niezliczonymi teoriami specyficznego poetyckiego języka. [...] „Widzieć” znaczy nie tylko mieć przed oczami, także przechować w pamięci, „widzieć i opisywać" znaczy odtwarzać w wyobraźni. Dystans, jaki stwarza tajemnica czasu, nie musi zmieniać wydarzeń, krajobrazów, twarzy ludzkich w gmatwaninę coraz bardziej blednących cieni. Przeciwnie, może je ukazywać w pełnym świetle, tak, że każdy fakt, że każda data na-

33 Prezentowane w wierszu rozumienie kategorii zapomnienia różni się od Ricoeurowskiego pojęcia śladu-odcisku (semeion) jako figury niewiernej pamięci, ale zasługującej na miano osobnej sztuki art oblivionis. Por. P. Ricoeur, op. cit., s. 562.

\section{1 Świadectwo obrazu}


biera wyrazu i trwa na wieczne przypomnienie ludzkiego znieprawienia, ale i ludzkiej wielkości. Ci, którzy żyją, otrzymują mandat od tych wszystkich, którzy umilkli na zawsze. Wywiązać się ze swego obowiązku mogą, tylko starając się odtworzyć dokładnie to, co było, wydzierając przeszłość zmyśleniom i legendom. Tak ziemia widziana $z$ wysoka, w wiecznym teraz, i ziemia trwająca $w$ odzyskanym czasie stają się na równi materiałem poezji ${ }^{34}$.

Inspirowany Cudowna podróżą Selmy Lagerlöf koncept unieruchomionego lotu doskonale lączy spojrzenie $\mathrm{z}$ góry i spojrzenie $\mathrm{z}$ dołu. Pierwsze z nich - „wieczne teraz" - odpowiada fazie postrzegania wzrokowego, ogarnięcia obrazu, selekcji jego elementów i artystycznego przetworzenia. Drugie - któremu przynależy „czas odzyskany” - koncentruje się w większym stopniu na pośredniczeniu pamięci, rekonstruowaniu jej w procesie pisania. Obydwa wszelako służą jednej sprawie: funkcjonalizacji ekfrazy i przypisaniu jej zadań regresywnych (sięganie do przeszłości), petryfikacyjnych (zachowanie danego stanu rzeczy w obrazie) oraz prospektywnych (krytyczna opieka nad tradycją).

${ }^{34}$ Cz. Miłosz, Zaczynając od moich ulic, Paryż 1985, s. 349. 